\title{
Partial Distance-Learning Training for Information Technology Higher Education Trainers
}

\author{
Ahmed Al Naamany, Hadj Bourdoucen, Joseph Jervase, Mohamed Elzain \\ Sultan Qaboos University, College of Engineering, \\ Muscat, Sultanate of Oman \\ Tel: $24141363,24141325,24141323$, \\ Emails: naamany@squ.edu.om or hadj@squ.edu.om or \\ jervase@squ.edu.om or melzain@squ.edu.om
}

\begin{abstract}
Teachers must be able to adapt to a rapidly changing IT knowledge and technology. This requirement is further compounded by the need that this knowledge and technology be incorporated in the curriculum at the same rate. This paper presents a strategic approach for updating curriculum and technical know-how of information technology through training the IT trainers. This approach is expected to help modernize the IT training in the developing country by educating the youth who are at the receiving end of this training. In order to ensure the economic feasibility of this approach, teaching methods conducted were based on a combination of traditional methods and modern distance learning techniques.
\end{abstract}

\section{Introduction}

Sustaining economic development is one of the main concerns of any developing nation. Years ago, labor and land were focal points of a healthy economy. They were dominating for many years, but since natural and energy resources were discovered; energy resources became the identity of a wealthy economic system. The technological development in the twentieth century lead many nations to change toward establishing an economic system based on knowledge and information; hence the birth of knowledge-based economy. Knowledge-based economy started to overtake both physical-based and energy-based economies. The reason for that shift is that knowledge is a never-ending source, whereas, natural and energy resources are limited [1]. 
This paper elaborates on an attempt to establish a foundation of knowledge-based economy in Oman and to encourage formation of essential ingredients to achieve United Nations Millennium Development Goals (MDGs) that require cooperation with the private and public sectors to make available the benefits of new technologies, especially information and communications technologies [2]. To achieve this goal, the team working in this project has targeted information technology higher education trainers for training using a partial distance teaching approach [3]. Distance learning is defined as the type of learning for which the instructor and the student are separated by either time or place or both, whereas, traditional learning requires the availability of both students and teachers in the same room at the same time [4].

\section{Distance learning}

Through distance learning, universities are able to accept a larger number of students to register in a course and to optimize the use of resources that would normally be required for conventional teaching techniques [5]. Distance learning can be convenient for students with disabilities [6]. There are different types of distance learning such as: mail course, web-based instruction, or video and/or audio tapes [7].

\subsection{Benefits of distance learning}

Distance learning is an effective approach since communication between people all around the world is possible due to all the technologies available. Distance learning can be beneficial in terms of quantity and quality, budget saving, flexibility, convenience, and support [8-10].

Distance learning also helps the students to be more organized and build their abilities to engage in long-life learning, which is very critical not only for students, but for teachers as well [8-10].

\subsection{Challenges to distance learning}

Although distance learning has become an attractive approach, the drop rate of distance learning students is higher than traditional classroom students. This high drop rate is due to the lack of motivation and self-discipline for some students enrolled in distance learning programs. However, there are still many challenges that affect the growth of distance learning approaches, such as course materials, scalability, exam monitoring, and labs $[6,10,11]$.

\section{Strategic plan for IT dissemination}

Some statistical results showed that the penetration level of internet usage in the Oman population is around $10.2 \%$ [12]. This percentage indicates that the level of 
internet knowledge among Omani people is not widely spread. In order to achieve a massive expansion in the use of information technology by all components of the society, a strategic plan was identified and developed to train a segment of the population that is in a front position to transfer this know-how to others. Information technology instructors in different training departments of various private and public institutions were identified as potential members of the population segment to be trained as IT trainers for Oman.

\section{Skill survey}

The potential trainers, consisting of 80 teachers, were surveyed to know their web, computer hardware, and networking skills. Based on these surveys, the team identified the weaknesses that needed to be addressed and what was required to structure a curriculum to retrain them. Since most of the trainers' teachers had the same weaknesses, then even teachers of the teachers required retraining in order to guarantee the same level of standards for the future teachers.

\subsection{Web skills know-how survey}

The web skills survey was not restricted to web browsing only; it also included the ability of the trainees to design web pages using Microsoft FrontPage or any HTML editor. Many web site designers use programs such as Flash or GIF to add attractive features to their web pages. Since this project aims to train the trainers, it is very important to know their levels using Microsoft Power Point.

\subsection{Computer skills know-how survey}

The Internet has actually materialized mainly because of the invention of computers. Therefore, the knowledge level of the teachers was surveyed to evaluate their computer skills. The survey conducted has shown the abilities of trainees in computer assembly, operating systems installation and troubleshooting, hardware troubleshooting, and configuring Internet connections.

\subsection{Networking skills know-how survey}

The survey conducted shows the trainees' level in network design, network background theory, implementation, and troubleshooting. Figure 1 summaries the statistics obtained for these surveys. 


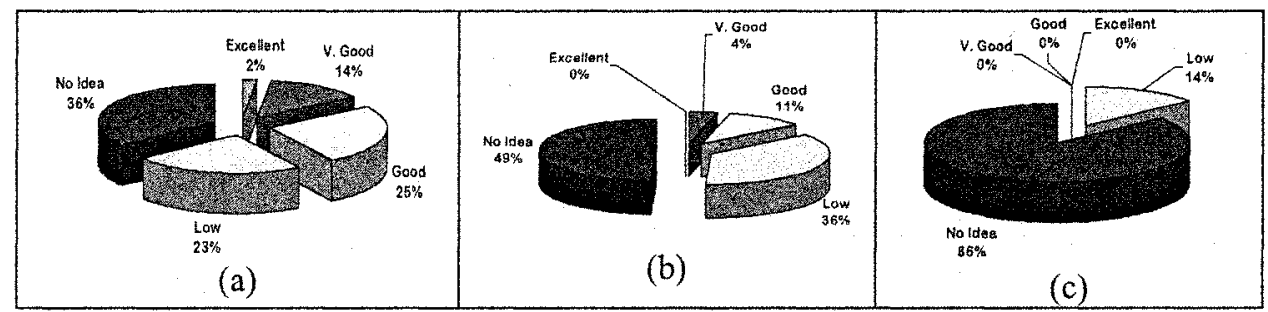

Figure 4. (a) Statistics of web skills know-how survey (b) Statistics of computer skills knowhow survey (c) Statistics of networking skills know-how survey [3].

Analyzing the statistics obtained in these surveys shows that at least $60 \%$ of the teachers have a little or no web skills, computer skills, or networking skills. Possible reasons for these high percentages are the rapid changes in technology, teachers' adaptation with the internet, and their education background. However, when it comes to network design the percentage doesn't appear to be surprising, because out of the whole world's population only $14.6 \%$ knows how to USE the internet, which means that the percentage of people who know how to design a network is below $14.6 \%[12]$.

\section{$5 \quad$ IT training and results}

An IT training plan was developed by the team that covers the weaknesses surveyed. This plan consists of:

1) CISCO HP IT Essentials (part I) Program Curriculum will be followed in the first part of the project. This curriculum is based on distance learning. It contains online material that helps the trainee in his/her study. Some animations are used in clarifying some of the online material (to know more about the curriculum see [13]).

2) An IT syllabus developed by the team members, which will be followed in the second stage of the project. It is based on traditional teaching. The syllabus will contain an introduction to networking, presentation methods, and multimedia \&web-based techniques.

This training program covers the weaknesses surveyed and it tends to raise the ICT level of the participants. Teachers who didn't have enough ability in any of the skills surveyed have a good understanding now that they have participated in this program that required them to do several tests/exams to guarantee that they have benefited from these courses.

This plan took into account that the trainers after finishing this curriculum will deliver what they learned to other teachers and students. This will guarantee the dissemination of IT throughout the country. 


\section{Conclusion}

It is anticipated that a successful completion of this project will stimulate extensive use of information technology in all areas of the national economy, including industry, education, trade and services. The team undertaking this project is interacting with the Ministries of Education and Higher Education to ensure compatibility of aims and benefits of information technology to the country.

It is the belief of the team working in this project that this work offers efficient and cost-effective means to disseminate ICT know-how in the Sultanate of Oman. It also works towards ensuring gender equality in ICT.

\section{Acknowledgement}

This work is part of an SQU Strategic Project \# ENG/ECED/04/01. The authors would like to thank SQU for allocating funds for this project.

\section{References:}

1. Knowledge economy, http://www.enterweb.org/know.htm

2. The UN Millennium Development Goals, http://www.un.org/millenniumgoals/

3. Ahmed M. Al-Naamany, Hadj Bourdoucen, Joseph A. Jervase, and Mohamed Elzain, "Training the Trainer through Partial Distance Learning Approach", ICODE 2006, Muscat March 2006.

4. Why distance learning, http://www.humanesocietyu.org/degrees_and_certificates/why_distance_learning.ht $\mathrm{ml}$

5. Celeste M. Walls. Some Strategies for Balancing Economies of Scale and Interaction in Online/Distance Education Courses. Link:

6. http://www.usq.edu.au/electpub/e-jist/docs/vol8_nol/fullpapers/Celeste_Walls.pdf

7. Diana G. Oblinger, Carole A. Barone \& Brain L. Hawkins (2001). Distributed Education and Its Challenges: An Overview. Washington, DC: American Council on Education.

8. Distance Learning, http://cops.uwf.edu/tutorials/technolo/distance/distance.htm

9. Benefits of distance learning, http://www.distancelearninginfo.com/benefits_of_distance_learning.html

10. University of Idaho, Engineering Outreach (1995). Distance Education: Research.

11. Timothy K. Shih (2002). "Distance Education Technologies: Current Trends and Software Systems". IEEE Computer Society.

12. Arthur Levine \& Jeffrey C. Sun (2002). Barriers to Distance Educations. Washington, DC: American Council on Education.

13. Internet Growth 2000 to 2005 in the world, http://www.internetworldstats.com/pr/edi008.htm

14. CISCO HP IT Essential, http://www.cisco.com/web/learning/netacad/downloads/779/edu/media/docs/final_H P031103.pdf 